\title{
ANALISIS POTENSI BAHAYA LINGKUNGAN KERJA PADA USAHA PENJAHIT Y DI KOTA PALEMBANG
}

\author{
Atidira Dwi Hanani \\ Universitas Indo Global Mandiri Palembang Sumatera Selatan, Indonesia \\ Email: atidira@uigm.ac.id
}

\begin{abstract}
This study aims to analyze the potential hazards of the work environment at $Y$ Tailor which can be useful as a basis for consideration in creating a safe work environment. The method used in this research is qualitative method. The collection of information related to the conditions of the work environment was obtained by doing in-depth interviews and observing the environmental conditions at $Y$ Tailor. The results showed various potential hazards in the work environment at $Y$ Tailor, such as physical, chemical, biological, ergonomic, and psychological hazards. This has caused complaints and health problems felt by the workers at Y Tailor, such as headaches, respiratory problems, musculoskeletal disorders, and work stress. There needs improvements in management related to a safe work environment as a strategy to maintain the safety and health of workers at $Y$ Tailor.
\end{abstract}

Keywords: hazard; environment; work; tailor.

\section{Abstrak}

Penelitian ini bertujuan untuk menganalisis potensi bahaya lingkungan kerja pada Usaha Penjahit $\mathrm{Y}$ yang dapat bermanfaat sebagai dasar pertimbangan untuk menciptakan lingkungan kerja yang aman. Metode yang digunakan dalam penelitian ini adalah metode kualitatif. Pengumpulan informasi yang berkaitan dengan kondisi lingkungan kerja didapatkan dengan melakukan wawancara mendalam dan observasi terhadap keadaan lingkungan pada Usaha Penjahit Y. Hasil penelitian menunjukan berbagai potensi bahaya lingkungan kerja di Usaha Penjahit Y mulai dari bahaya fisik, kimia, biologi, ergonomi, hingga bahaya psikososial. Hal ini menimbulkan keluhan dan masalah kesehatan yang dirasakan oleh para pekerja di Usaha Penjahit Y seperti sakit kepala, gangguan pernafasan, gangguan musculoskeletal, hingga stres kerja. Perlu ada perbaikan manajemen terkait lingkungan kerja yang aman sebagai startegi menjaga keselamatan dan kesehatan pekerja pada Usaha Penjahit Y.

Kata Kunci: bahaya; lingkungan; kerja; penjahit.

\section{Pendahuluan}

Usaha penjahit adalah tempat kerja yang bergerak dalam bidang produksi dan perbaikan pakaian, baik yang digunakan untuk keperluan suatu acara maupun kebutuhan sehari-hari. Usaha ini terus mengalami kemajuan di berbagai negara. Pakaian yang merupakan kebutuhan dasar bagi setiap orang membuat usaha penjahit saat ini 
semakin dicari oleh banyak orang. Usaha ini dinilai cukup menjanjikan dengan keuntungan yang tidak sedikit. Di Indonesia, industri di bidang pakaian terus berkembang dimana-mana, termasuk di Kota Palembang.

Kota Palembang merupakan salah satu kota yang cukup terkenal dalam dunia fashion. Beragam acara pameran pakaian sering dilaksanakan oleh para perancang busana dan penjahit di Kota Palembang. Namun, di sisi lain terdapat banyak keluhan dan masalah kesehatan yang dirasakan oleh para penjahit pakaian yang pada akhirnya dapat menimbulkan tingginya angka penyakit akibat kerja. Hasil penelitian menunjukkan terdapat keluhan gangguan muskuloskeletal pada pekerja jahit berupa sakit atau kaku pada berbagai anggota tubuh mulai dari leher, bahu, lengan, punggung dan pinggang, bokong dan pantat, hingga pada bagian kaki (Wulandari, Moelyaningrum, \& Hartanti, 2017).

Penyakit akibat kerja muncul akibat adanya potensi bahaya di lingkungan kerja. Menurut International Labour Organization (2013), potensi bahaya merupakan sesuatu yang memiliki kemungkinan untuk terjadinya insiden yang dapat menimbulkan kerugian. Penelitian ini bertujuan untuk menganalisis potensi bahaya lingkungan kerja di Usaha Penjahit Y sebagai upaya untuk mencegah timbulnya kerugian akibat adanya insiden yang tidak diharapkan. Menurut hasil penelitian (Wati, 2020), terdapat berbagai potensi bahaya pada usaha produksi pakaian rumahan mulai dari potensi bahaya yang bersumber dari listrik, mekanik, fisika, ergonomi, kimia, hingga potensi bahaya psikososial. Analisa terhadap potensi bahaya lingkungan kerja penting untuk dilakukan sebagai salah satu dasar pertimbangan untuk menghindari kecelakaan dan penyakit akibat kerja. Namun, masih sedikit pekerja seperti penjahit yang memperhatikan potensi bahaya di lingkungan tempat kerjanya, padahal angka kesakitan di industri seperti ini terbilang cukup tinggi.

Berbagai keluhan dirasakan oleh para penjahit di Usaha Penjahit Y. Usaha Penjahit Y merupakan salah satu usaha penjahit pakaian yang berada di Kota Palembang. Lokasi nya yang strategis membuat usaha penjahit ini ramai dikunjungi para pengguna jasa penjahit. Letak usaha jahit yang berada di pinggir jalan utama ini juga membuat lingkungan kerja yang kurang kondusif karena adanya berbagai hal yang mengganggu seperti kebisingan dari suara kendaraan yang melintas, polusi udara yang juga mencemari ruangan menjahit yang terbuka, dan berbagai hal terkait lingkungan kerja yang akan dianalisis dalam penelitian ini.

Lingkungan kerja dalam usaha penjahit perlu diperhatikan, karena lingkungan kerja memiliki dampak terhadap kondisi penjahit. Lingkungan kerja yang aman dan sehat dapat membuat penjahit bekerja dengan baik dan sebaliknya, lingkungan kerja yang tidak dirancang dengan baik akan dapat menurunkan hasil kerja penjahit tersebut. Keadaan lingkungan kerja dinilai baik jika para pekerja dapat melakukan proses menjahit tanpa merasakan berbagai keluhan atau terganggu dengan bahaya yang ada di sekitar. Lingkungan kerja yang kurang baik dapat membuat para penjahit tidak nyaman sehingga memerlukan durasi pengerjaan yang lebih lama dalam menyelesaikan pekerjaannya, sehingga pada akhirnya berpengaruh pada produktivitas kerja. 
Lingkungan kerja terbukti memiliki pengaruh terhadap produktivitas kerja, sebagaimana hasil penelitian Budiastuti (2011) yang menunjukkan bahwa lingkungan kerja adalah hal yang berhubungan erat dengan produktivitas kerja operator jahit pada usaha konveksi.

Produktivitas pekerja yang baik dapat tercipta salah satunya dengan menyelenggarakan upaya Keselamatan dan Kesehatan Kerja (K3). Pemilik usaha perlu melaksanakan K3 untuk melindungi pekerja dari hal-hal yang mengancam keselamatan dan kesehatan para pekerja nya. Hal ini juga yang nantinya akan berpengaruh pada peningkatan produktivitas pekerja dan dapat mempengaruhi kualitas barang yang dihasilkan (Aditama \& Hastuti, 2002). Jika keselamatan dan kesehatan pekerja terpelihara dengan baik maka dapat tercipta lingkungan kerja yang aman dan pekerja menjadi sehat dan produktif.

\section{Metode Penelitian}

Metode yang digunakan dalam penelitian lingkungan kerja pada Usaha Penjahit Y di Kota Palembang ini adalah metode kualitatif. Pengumpulan informasi yang berkaitan dengan kondisi lingkungan kerja didapatkan dengan melakukan wawancara mendalam (indepth interview) dan observasi terhadap keadaan lingkungan pada Usaha Penjahit $\mathrm{Y}$ mulai dari tata tempat, peralatan, durasi kerja, suasana kerja, hingga lingkungan sekitar tempat kerja. Hal ini dilakukan untuk mendapatkan informasi mengenai kondisi lingkungan kerja yang ada saat ini sebagai bahan untuk perbaikan ke depan.

Total informan dalam penelitian ini adalah 12 orang yang terdiri dari 11 orang pekerja yang merupakan penjahit di Usaha Penjahit $\mathrm{Y}$, dan 1 orang pemilik Usaha Penjahit Y sebagai informan kunci. Selanjutnya, peneliti juga melakukan pengamatan secara langsung ke tempat Usaha Penjahit Y untuk menilai kondisi lingkungan kerja tersebut.

Peneliti menggunakan pedoman wawancara yang berisi pertanyaan seputar lingkungan kerja sebagai alat bantu saat proses wawancara dengan para informan sehingga wawancara lebih tearah dan mendapatkan informasi yang lengkap. Dalam melaksanakan observasi, peneliti menggunakan pedoman dan tabel observasi serta kamera untuk dokumentasi.

Peneliti melakukan pengecekan kebenaran data yang didapatkan sebagai upaya menjaga keabsahan informasi yang disajikan dalam hasil penelitian. Pengecekan data dapat dilakukan dengan metode triangulasi sumber dan metode (Sugiyono, 2010). Triangulasi sumber diterapkan dengan melakukan pengumpulan data dari beberapa informan dan mengecek keakuratan data dari berbagai sumber tersebut (Komariah, 2010). Dalam penelitian ini, yang menjadi sumber informasi bukan hanya pemilik usaha tetapi juga pekerja yang juga menjadi informan dalam penelitian ini. Penggunaan metode pengumpulan data yang lebih dari satu berupa observasi dan wawancara mendalam merupakan salah satu bentuk triangulasi metode yang diterapkan dalam penelitian ini. 


\section{Hasil dan Pembahasan}

Jumlah informan dalam penelitian ini adalah 12 orang. 11 orang informan adalah pekerja yang merupakan penjahit di Usaha Penjahit $\mathrm{Y}$, dan 1 orang pemilik Usaha Penjahit Y sebagai informan kunci. Karakteristik informan ini meliputi usia dan masa kerja. Data tersebut ditampilkan pada tabel 1.

Tabel 1

Karakteristik Informan

\begin{tabular}{|c|c|c|}
\hline Karakteristik Informan & Jumlah & Persentase \\
\hline \multicolumn{3}{|l|}{ Usia } \\
\hline$<25$ tahun & 3 & $25,0 \%$ \\
\hline 25-50 tahun & 7 & $58,3 \%$ \\
\hline$>50$ tahun & 2 & $16,7 \%$ \\
\hline Total & 12 & $100 \%$ \\
\hline \multicolumn{3}{|l|}{ Masa Kerja } \\
\hline$<5$ tahun & 6 & $50,0 \%$ \\
\hline 5-10 tahun & 4 & $33,3 \%$ \\
\hline$>10$ tahun & 2 & $16,7 \%$ \\
\hline Total & 12 & $100 \%$ \\
\hline
\end{tabular}

Tabel 1 menunjukkan data yang diperoleh dari hasil wawancara bahwa sebagian besar informan berada pada usia dewasa yaitu antara 25-50 tahun. Terdapat 3 orang pekerja yang masih muda (usia $<25$ tahun) dan ini merupakan pekerja baru yang ada di Usaha Penjahit Y. Masa kerja dari penjahit ini juga bervariasi, ada yang sudah bekerja sebagai penjahit lebih dari 10 tahun, namun sebagian besar baru bekerja kurang dari 5 tahun.

Berdasarkan hasil wawancara dan observasi, potensi bahaya lingkungan kerja pada Usaha Penjahit Y di Kota Palembang dapat dijabarkan sebagai berikut:

\section{A. Potensi Bahaya Fisik}

Potensi bahaya fisik yang ditemukan di Usaha Penjahit $\mathrm{Y}$ berasal dari getaran, kebisingan, suhu udara, dan tata ruang yang tidak didesain dengan baik. Getaran berasal dari dynamo mesin yang menggerakkan mesin jahit. Apabila paparan getaran tersebut terjadi secara berulang, maka dapat memberikan efek bagi pekerja, misalnya kaki menjadi kaku dan terjadinya disfungsi syaraf. Getaran merupakan salah satu faktor risiko terjadinya penyakit atau masalah kesehatan pada anggota tubuh pekerja. Masalah kesehatan yang dapat dirasakan oleh penjahit diantaranya adalah carpal tunnel syndrome yang membuat tangan mengalami nyeri atau lemah dan berdampak pada penurunan hasil kerja dari penjahit (Wati, 2020).

Kebisingan berasal dari suara mesin jahit yang cukup berisik jika digunakan, kebisingan akan bertambah jika seluruh mesin jahit di tempat usaha penjahit $\mathrm{Y}$ digunakan secara bersamaan oleh seluruh pekerja. Selain itu, letak usaha penjahit Y yang berada di pinggir jalan raya dapat menambah tingkat kebisingan lebih tinggi akibat suara kendaraan yang berlalu lalang di jalan. Nilai Ambang Batas (NAB) kebisingan adalah $85 \mathrm{dBA}$ untuk 8 jam pemaparan. Dengan jam kerja para penjahit 
yang lebih dari 8 jam per hari nya, apabila pekerja terpapar kebisingan secara berulang dalam waktu yang lama maka akan berdampak pada gangguan pendengaran para pekerja. Hasil penelitian sebelumnya menunjukkan bahwa paparan kebisingan yang ada di tempat kerja berbanding lurus dengan gangguan pendengaran para pekerja (Dewanty \& Sudarmaji, 2015). Kebisingan ini juga dapat mengurangi konsentrasi pekerja saat menjahit, apabila mereka kehilangan konsentrasi tentu risiko tertusuk jarum tidak dapat terhindari.

Lokasi usaha penjahit ini berada di pinggir jalan raya dan dalam ruangan terbuka, suhu panas pada siang hari akan sangat terasa walaupun telah menggunakan kipas angin. Panas juga dirasakan oleh penjahit dari cahaya lampu yang panas dan berada sangat dekat dengan mesin jahit. Kondisi ini bisa mengakibatkan pekerja tidak konsentrasi dan tidak nyaman saat berkerja.

Usaha penjahit ini memiliki ukuran ruangan yang kecil untuk ditempati oleh 11 orang penjahit dalam melakukan pekerjaan. Ruang kerja yang tidak terlalu luas menyebabkan ruang gerak pekerja menjadi terbatas. Selain karena ketersediaan lahan bangunan yang minim, banyaknya barang yang ada di ruang tersebut juga membuat ruangan terasa semakin sempit dan sedikit ruang untuk bergerak. Hal ini mengakibatkan para pekerja lebih sering duduk di posisi masing-masing dalam waktu yang lama. Kegiatan bekerja dengan posisi yang sama ini seharusnya tidak dilakukan secara berkesinambungan karena dapat membuat pekerja cepat lelah.

\section{B. Potensi Bahaya Kimia}

Pada usaha penjahit $\mathrm{Y}$ juga ditemukan risiko terpapar bahan kimia. Potensi bahaya kimia yang terlihat di lokasi kerja penjahit Y antara lain berasal dari debu, polusi, oli, dan pelumas mesin. Oli dan pelumas mesin yang digunakan oleh penjahit apabila tidak diletakkan pada tempatnya dapat mengkontaminasi makanan, atau jika oli dan pelumas mesin itu tumpah ke lantai dapat menyebabkan orang terpeleset, dan bila terkena api dapat terjadi kebakaran.

Tempat usaha penjahit yang berada di pinggir jalan raya tentunya tidak bisa terbebas dari polusi atau gas buangan yang dikeluarkan oleh kendaraan. Jika pekerja terpapar polusi setiap saat dari waktu ke waktu, maka dapat mempengaruhi kesehatan pekerja. Misalnya, terpapar gas CO dimana gas CO memiliki efektivitas 245 kali lebih besar berikatan dengan hemoglobin $(\mathrm{Hb})$ dibandingkan Oksigen $\left(\mathrm{O}_{2}\right)$ (Dewanti, 2018). Hal ini menyebabkan tubuh pekerja kekurangan Oksigen dan mengalami keluhan sakit kepala, gangguan pada pernafasan dan pencernaan, sampai hilang kesadaran. Zat polutan yang mengkontaminasi udara tidak hanya mempengaruhi kesehatan manusia tetapi efek dari pencamaran udara tersebut juga berdampak pada seluruh makhluk hidup dan lingkungan (Abidin \& Hasibuan, 2019). Sebagai upaya pencegahan, pekerja dapat memakai masker saat berada di lingkungan Usaha Penjahit Y. Dalam penelitian Purwanti (2014) disebutkan bahwa masker berfungsi mencegah gangguan pada sistem pernafasan dengan cara menyaring partikel dalam udara yang dihirup pekerja dan membuat partikel tersebut terendap pada filter yang ada pada masker tersebut. 


\section{Potensi Bahaya Biologi}

Sumber bahaya biologi yang ada di lingkungan kerja adalah organisme seperti hewan dan tumbuhan (Ramli, 2010). Berdasarkan hasil observasi, lingkungan kerja di tempat usaha Penjahit Y tampak kotor dan lembab. Hal ini menyebabkan mikroorganisme seperti jamur, virus, dan bakteri dapat berkembang biak. Mikroorganisme tersebut juga dapat berasal dari kain/pakaian yang mereka jahit sehingga dapat memungkinkan pekerja terkena penyakit akibat kerja karena terinfeksi jamur, virus, dan bakteri tersebut. Ketika pekerja melakukan pemilihan terhadap kain yang dijahit, sebaiknya para pekerja menggunakan masker dan rajin mencuci tangan untuk menghindari mikroorganisme masuk ke dalam tubuh. Masker terbukti dapat melindungi saluran pernafasan dari debu atau partikel yang masuk ke dalam tubuh. Masker yang digunakan dapat terbuat dari kain dan dirancang dengan berbagai ukuran yang disesuaikan dengan antropometri tubuh para pengguna (Miftasari, 2012).

\section{Potensi Bahaya Ergonomi}

Pada usaha penjahit Y ditemukan beberapa potensi bahaya ergonomi seperti posisi tubuh yang salah saat menjahit. Durasi menjahit yang lama membuat para penjahit berada pada posisi duduk dalam waktu berjam-jam. Saat bekerja, para penjahit menggunakan berbagai otot dari kepala, leher, punggung, sampai kaki yang bergerak dengan tempo cepat dan berulang. Posisi kerja seperti ini dapat mengakibatkan penyakit akibat kerja seperti Musculoskeletal disorders (MSDs). Menurut penelitian Mayasari \& Saftarina (2016), gangguan muskuloskeletal dapat berasal dari pajanan ergonomi saat bekerja seperti postur yang tidak pas serta gerakan yang berlangsung berkali-kali. Hal ini terjadi pada penjahit di Usaha Penjahit $\mathrm{Y}$ yang bekerja dengan posisi yang sama secara berulang. Keluhan yang dirasakan penjahit juga disebabkan oleh kursi yang digunakan saat menjahit tidak memiliki sandaran. Hal ini menyebabkan tubuh menjadi lebih cepat lelah karena tidak ada yang menopang bagian belakang tubuh dan kepala. Untuk itu, kursi yang digunakan sebaiknya memiliki sandaran dan meja yang digunakan didesain sesuai dengan postur tubuh pekerja agar pekerja dapat merasa nyaman dan aman. Penelitian Amri, Fatimah, \& Yusnidar (2015) menggambarkan kursi yang ergonomis untuk pekerja diantaranya memiliki sandaran punggung dan dilengkapi dengan bantalan.

\section{E. Potensi Bahaya Psikososial}

Penyakit akibat kerja juga disebabkan oleh penyebab yang bersifat psikososial seperti stres psikis, monotoni kerja, dan tuntutan pekerjaan (Yadi, 2015). Potensi bahaya psikososial yang ditemukan dalam usaha penjahit ini adalah perasaan jenuh para pekerja ketika pesanan sudah melebihi kapasitas kerja masingmasing penjahit. Permintaan para pengguna jasa jahit untuk dapat selesai dalam waktu yang cepat menjadi tantangan tersendiri bagi para pekerja di Usaha Penjahit Y. Selain itu, jam kerja yang terlalu lama yakni dimulai pukul 08.00 wib - 21.00 wib (lebih dari 8 jam per hari) menjadi beban tambahan bagi pekerja sehingga 
produktivitas cenderung menurun. Hal ini serupa dengan hasil penelitian yang dilakukan oleh Wartono \& Mochtar (2015) yang menyatakan bahwa stres kerja dapat terjadi karena adanya pekerjaan tambahan yang harus segera diselesaikan, jam kerja yang melebihi batas waktu kerja normal, serta kejenuhan dalam bekerja. Untuk menghindari keluhan dalam masalah psikososial, pekerja dapat menjaga hubungan baik antar penjahit, pemilik usaha, dan pengguna jasa.

Secara keseluruhan, hasil observasi dan wawancara menunjukkan berbagai kondisi di lingkungan kerja Usaha Penjahit Y yang dapat menimbulkan risiko kecelakaan kerja. Untuk mengurangi resiko kecelakaan kerja seperti tertusuk, luka atau tergores akibat jarum dan gunting, pemilik usaha mengingatkan kepada para pekerja untuk lebih hati-hati dalam menggunakan benda-benda tajam tersebut dan menyediakan fasilitas kesehatan berupa alat-alat P3K sebagai pertolongan pertama jika terjadi cedera.

\section{Kesimpulan}

Masalah kesehatan yang dirasakan oleh para pekerja di Usaha Penjahit Y terdiri dari sakit kepala, sakit pada lengan dan pinggang, gangguan pernafasan, gangguan musculoskeletal, hingga stres kerja. Masalah kesehatan ini terjadi akibat adanya potensi bahaya di lingkungan kerja, mulai dari bahaya fisik (getaran, kebisingan, suhu, dan cahaya), kimia (debu, polusi udara, oli dan pelumas mesin), biologi (mikroorganisme), ergonomi (posisi tubuh dan alat kerja yang tidak ergonomis), hingga bahaya psikososial (stres kerja). Perbaikan manajemen terkait lingkungan kerja yang aman perlu diterapkan sebagai startegi menjaga keselamatan dan kesehatan pekerja pada Usaha Penjahit Y.

\section{BIBLIOGRAFI}

Abidin, J., \& Hasibuan, A. F. (2019). Pengaruh Dampak Pencemaran Udara Terhadap Kesehatan Untuk Menambah Pemahaman Mayarakat Awam Tentang Bahaya Dari Polusi Udara. Prosiding SNFUR, 4, 2-3.

Aditama, T. Y., \& Hastuti, T. (2002). Kesehatan dan keselamatan kerja. Penerbit Universitas Indonesia.

Amri, Fatimah, \& Yusnidar. (2015). Perancangan Kursi yang Ergonomis sebagai Alat Bantu di Stasiun Kerja Produksi Air Galon (Studi Kasus PT. Ima Montaz Sejahtera). Malikussaleh Industrial Engineering Journal, 4(2), 17-23.

Budiastuti, L. D. (2011). Faktor-faktor yang Mempengaruhi Produktivitas Kerja Operator Jahit pada Konfeksi Amanah di Gunungpati Semarang. Universitas Negeri Semarang.

Dewanti, I. R. (2018). Identifikasi paparan co, kebiasaan, dan kadar cohb dalam darah serta keluhan kesehatan di basement apartemen waterplace, Surabaya. Jurnal Kesehatan Lingkungan, 10(1), 59-69.

Dewanty, R. A., \& Sudarmaji. (2015). Analisis Dampak Intensitas Kebisingan Terhadap 
Analisis Potensi Bahaya Lingkungan Kerja Pada Usaha Penjahit Y di Kota Palembang

Gangguan Pendengaran Petugas. Jurnal Kesehatan Lingkungan, 8(2), 229-237.

International Labour Organization. (2013). Keselamatan dan Kesehatan Kerja di Tempat Kerja (Sarana untuk Produktivitas). (5th ed.). Jakarta: International Labour Organization.

Komariah, D. S. (2010). Aan. Metodologi Penelitian Kualitatif, Bandung: Alfabeta.

Mayasari, D., \& Saftarina, F. (2016). Ergonomi sebagai Upaya Pencegahan Musculoskeletal Disorders pada Pekerja. Jurnal Kedokteran Dan Kesehatan Universitas Lampung, 1(2), 369-379.

Miftasari, A. I. (2012). Hubungan Antara Kadar Debu dan Pemakaian Masker dengan Kapasitas Vital Paru pada Pekerja Bagian Pengamplasan UD. Putra Kusuma Jati di Kelurahan Jepon Kabupaten Blora Tahun 2011. Universitas Negeri Semarang.

Purwanti, I. (2014). Hubungan pemakaian Masker terhadap Kapasitas Vital Paksa dan volume Ekspirasi Paksa Detik Pertama pada Pekerja Pengolahan Kelapa Sawit PT. Perkebunan Nusantara XIII Rimba Belian Kabupaten Sanggau. Naskah Publikasi Fakultas Kedokteran, Universitas Tanjungpura.

Ramli, S. (2010). Sistem manajemen keselamatan dan kesehatan kerja OHSAS 18001. Jakarta: Dian Rakyat.

Sugiyono. (2010). Metode Penelitian Kuantitatif Kualitatif dan $R$ \& D. Bandung: Alfabeta.

Wartono, T., \& Mochtar. (2015). Stres dan kinerja di lingkungan kerja yang semakin kompetitif. Jurnal Ilmiah Prodi Manajemen Universitas Pamulang, 2(2), 153-171.

Wati, I. S. (2020). Potensi Bahaya pada Home Industry Konveksi. HIGEIA (Journal of Public Health Research and Development), 4(3), 384-397.

Wulandari, D. R., Moelyaningrum, A. D., \& Hartanti, R. I. (2017). Risiko Ergonomi Dan Keluhan Muskuloskeletaldisorders Pada Pekerja Jahit (Studi di UD. Ilfa Jaya Konveksi Banyuwangi-Indonesia). In Prosiding Seminar Dalam Rangka OSH Week (pp. 113-119).

Yadi, Y. H. (2015). Konsep Rancangan Alat Ukur Resiko Ergonomi. Journal Industrial Servicess, 1(1). 